\title{
IMÁGENES CALIFALES EN LOS JARDINES DEL ALCÁZAR DE SEVILLA
}

\author{
POR RAFAEl Cómez RAMOS
}

\begin{abstract}
Este artículo trata sobre la pervivencia de imágenes islámicas en los jardines del Alcázar de Sevilla del siglo XVII. El análisis de ciertas fuentes califales de mármol (s. X) y sus caños figurados demuestra su uso en los jardines renacentistas como un símbolo de poder.

This paper dealt with hispano-islamic images in the Alcazar of Seville XVI th century gardens. The analysis of certain marble bassins from Caliphate period (s. X) demonstrates their use for the Renaissance gardens as a symbol of power.
\end{abstract}

En varias ocasiones se ha destacado el papel trascendente que desempeñó el arte islámico en la conformación del espacio manierista en los jardines de los principales palacios reales del Renacimiento español ' . Este fenómeno estético, que no cabe explicarlo dentro de los estrechos parámetros positivistas de la mera "pervivencia" o "influencia" del arte hispanomusulmán en la arquitectura renacentista sino más bien dentro de los problemas de gusto artístico por determinadas formas e imágenes que conllevaban concretas razones de prestigio por su

1. BONET CORREA, A.: "El Renacimiento y el Barroco en los jardines musulmanes españoles", Cuadernos de la Alhambra, n. ${ }^{9} 4$, Granada, 1968, publicado posteriormente en la obra del mismo autor, Andalucía monumental. Arquitectura y ciudad del Renacimiento y Barroco, Biblioteca de la cultura andaluza, Barcelona, 1986, pp. 11-32. JIMÉNEZ MARTÍN, A.: "Jardines", Gran Enciclopedia de Andalucía, V, Sevilla, 1979, pp. 2.135-2.144. CHECA, F.: "El arte islámico y la imagen de la naturaleza en la España del siglo XVI", Fragmentos, n. ${ }^{\circledR}$ 1, Madrid, 1984, pp. 23-43. Véase también HANSMANN, W.: Jardines del Renacimiento y Barroco, con un apéndice de RABANAL YUS, A.: "Jardines del Renacimiento y Barroco en España", Madrid, 1989, y en general, BAZÍN, G.: Paradeisos. Historia del Jardín, Barcelona, 1990. 
lujo, refinamiento y sofisticación como símbolos de poder, se hace evidente en los jardines del Alcázar de Sevilla.

Mientras que los jardines nazaríes del Generalife fueron tratados respetuosamente por sus nuevos moradores, contratándose a albañiles y jardineros moriscos que los mantuvieran y conservaran ${ }^{2}$, los jardines sevillanos del Alcázar experimentaron una curiosa transformación por la cual sin perder su anterior estructura y aprovechando la antigua red hidráulica se revistieron con las galas del "Ars Nova" sin olvidar su vieja función de esparcimiento y diversión, de tal manera que se fusionaron admirablemente el conceptismo medieval islámico de la naturaleza con el carácter ambiguo, ecléctico, "dilettante" y refinado de la mentalidad manierista.

Persistía en ellos la imagen del Paraíso islámico, el lugar maravilloso, digno de los justos, que prometía el Profeta a aquellos bienaventurados que abrazaban la fe musulmana y cumplían su ley. Del mismo modo que una vieja "qubba" abbadí había sido transformada en uno de los más bellos ejemplos del Renacimiento español al convertirse en Cenador de la Alcoba así también el muro almohade de la alcazaba exterior se metamorfoseaba en fantástico belvedere manierista enmascarándose con la Galería del Grutesco ${ }^{3}$.

Ahora bien, no sólo se aproximaban al arte islámico por las evidentes razones de prestigio que poseía el lujo y refinamiento orientales de la Edad Media hispanomusulmana sino también por la admiración hacia el arte de construir de quienes no fueron nunca vencidos en el campo de la arquitectura. Conocido es el juicio del emperador Carlos $\mathrm{V}$ cuando se destruyó el bosque de columnas de la Mezquita de Córdoba para construir la actual Catedral:

"Si hubiese sabido lo que proyectabais hacer aquí, no lo habríais llevado a cabo, pues lo que vosotros habéis realizado es cosa que se puede ver en cualquier parte; pero lo que había antes de ello no existe en ningún lugar del mundo" 4 .

2. CHECA, F.: Op. cit., p. 30.

3. MARÍN FIDALGO, A.: Vermondo Resta, Sevilla, 1989, p. 138; eadem, El Alcázar de Sevilla bajo los Austrias, Sevilla, 1990; véase JIMÉNEZ, A.: "Dibujos de arquitectura sevillana. El Cenador de la Alcoba", Revista de Arte sevillano, n.․ 2, 1982, pp. 51-56; CHUECA GOITIA, F.: Arquitectura del siglo XVI, "Ars Hispaniae" XI, p. 20-8; LLEÓ, V.: Nueva Roma. Mitología y Humanismo en el Renacimiento sevillano, Sevilla, 1979; MORALES, A. et alii: Arquitectura del Renacimiento en España (1488-11599), Madrid, 1989, pp. 111-115. Sobre la muralla de la Galería del Grutesco véase VALOR, M.: La arquitectura militar y palatina en la Sevilla musulmana, Sevilla, 1991, pp. 217-222. Sobre la repercusión de las tipologías españolas en la arquitectura palatina italiana véase G. KERSCHER, "Islamische Kultur für den Osten? Ein verlorener islamischer Palast in Italien und seine Nachfolge", Kritische Berichte. Zeitschrift für Kunst und Kulturwissenschaften, 1/1992, pp. $29-42$.

4. APUD, K. OTTO-DORN.: El Islam, Barcelona, 1965, p. 148. 
En el Alcázar de Sevilla se mantuvo el antiguo dispositivo hidráulico y su red de fuentes y acequias, pero también, curiosamente, algunas tazas de fuentes califales con sus viejos caños en forma de cabezas de felinos igual que toda una serie de hermosos capiteles del siglo $\mathrm{X}$, trasplantados entre 1613 y 1621, para soportar las arcadas de la Galería del Grutesco. Ya no bastaba "el dorado techo fabricado por sabio moro" y el lujuriante espacio de los jardines con su marmóreo mobiliario arquitectónico se ofrecía como baluarte de gloria a la decadente monarquía de los Austrias. De las imágenes califales que percibimos en aquéllos tratarán las páginas que siguen.

En primer lugar, si nos detenemos en el ángulo Sudoeste del Patio de la Montería, justamente, en el extremo donde se inicia la galería que antecede al Cuarto del Almirante, podremos contemplar una pequeña fuente que fue colocada allí en época moderna. Se trata de un sencillo ejemplar marmóreo cuya taza gallonada de doce cascos se apoya en un fuste cilíndrico con ornamentación sogueada. Este tipo de fuentes de mármol blanco con forma gallonada en cascos redondos o, a veces, también picudos, está documentada en tiempos del Califato de Córdoba y fueron reutilizadas por los nazaries, como una existente en Granada con inscripción laudatoria a al-Hakam II, e intervención de su visir Chafar, fechada en el año 970. Otra de ellas, sin inscripciones, se conserva en la Real Academia de la Historia, en Madrid, y la mayor de todas, en la Alhambra, que fue utilizada como pila bautismal, consta de doce cascos alternantes, afirmando Gómez Moreno que éstas fueron "formas muy en favor bajo el Califato" 5 .

Mantiene su surtidor en bronce de aspecto fusiforme y ha perdido dos de los tres caños que tenía embutidos en el mármol de la taza. Estos eran figurados con cabezas de felinos como el que aún conserva y pasamos a analizar a continuación.

Consiste en una cabecita de largo pescuezo con las fauces entreabiertas y las orejas levantadas. No conocemos ningún caño figurado semejante a éste, sin embargo, la forma del animal recuerda la de las cabecitas de león que sostienen las anillas del mortero procedente de Monzón de Campos, que se encuentra en el Museo de Balaguer de Villanueva y Geltrú ${ }^{6}$. Presenta el típico tratamiento

5. GÓMEZ MORENO, M.: Arte árabe español hasta los almohades. Arte mozárabe, "Ars Hispaniae", III, Madrid, 195I, p. 191.

6. TORRES BALBÁS, L.: "Arte califal" en Historia de España dirigida por R. Menéndez Pidal, Madrid, 1957, pp. 750-751, fig. 587. Vid Al Andalus. Las artes islámicas en España, ed. de J. Dodds, Madrid, 1992, p. 270. 
sintético que muestran las figuras animales en la plástica califal y podría señalarse otro paralelismo, estableciendo cierta relación de semejanza con las cabezas de unos pies de bronce hallados en Medina Elvira, del Museo Arqueológico de Granada ?

No obstante, cuando la contemplamos de perfil, hallamos mayor similitud con algunos relieves marmóreos del mismo período y procedentes de Córdoba, singularmente, con un fragmento de pila del Moroquil que ostenta dos cabecitas de fieras flanqueando un tallo ${ }^{8}$. En realidad, se trata de ese animal -antítesis del león clásico- omnipresente en la ornamentación califal, que aparece también en la pila de Alamiría desmintiendo el supuesto aniconismo islámico.

$\mathrm{Y}$ es que el siglo $\mathrm{X}$, sobre todo en la época final del Califato, hacia el año 1000 , fue el momento de esplendor de las artes decorativas hispanomusulmanas, en las que abundaron las imágenes aún dentro del poderoso esquema de abstracción del arte islámico. Su extraordinario despliegue visual no se explica sin el concurso de la literatura en donde el tema del león es una constante metáfora poética ${ }^{9}$. Y, por otra parte, revela que el fanatismo e intolerancia religiosa malikí fue más aparente que real, mostrando la situación social de un mundo en crisis, escéptico, que sólo creía en la contemplación de la belleza.

Continuando nuestro itinerario por los patios del Alcázar, llegamos al llamado Jardín de Troya, trazado probablemente por el arquitecto milanés Vermondo Resta y construido por el albañil Pedro de Torres en $1606^{10}$. Este jardín, situado entre el muro meridional del Palacio del Rey Don Pedro y la cerca del Jardín de las Damas, supone un punto intermedio entre el Jardín de la Danza y el Jardín de las Flores, escalonados para el discurrir del agua desde el estanque de Mercurio al Jardín de la Galera. Según los viejos artificios hidráulicos musulmanes y por efecto de sifón, el líquido elemento brota rumoroso de la fuente.

En este caso, apoyándose en un fuste cilíndrico liso, la taza de doce gallones dobla en dimensiones a la descrita anteriormente. Conserva dos caños de figuras animales similares a aquéllas -uno de ellos muy erosionado y desgastado- por

7. TORRES BALBÁS, L.: Op. cit., p. 759, fig. 610.

8. GÓMEZ MORENO, M.: Op. cit., p. 181, fig. 245.

9. PÈRES, H.: La poésie andalouse en arabe classique au XI siecle. Ses aspects généraux et sa valeur documentaire, París, 1937, passim; sobre la relación entre la literatura y el arte califa véase CÓMEZ, R.: "Un tema iconográfico oriental antiguo en el arte hispano musulmán del siglo XI", Homenaje al Profesor Dr. Hernández Díaz, Universidad de Sevilla, 1982, recogido después en el libro del mismo autor, Imagen y símbolo en la Edad Media andaluza, Sevilla, pp. 15-34; sobre el tema de la iconografía hispanomusulmana véase PAVÓN MALDONADO, B.: "Arte, símbolo y emblemas en la España musulmana", Al Qantara, VI, 1985, pp. 397-450. El mejor estudio dedicado a estos aspectos iconográficos andalusíes es el de la profesora BAER, E.: "The Pila of Jativa: A document of Secular Urban Art in Western Islam", Kunst des Orient, VII, 2, 1970-71, pp. 142-66.

10. MARÍN FIDALGO, A.: Vermondo Resta, p. 142; eadem, El Alcázar..., II, p. 373. 
los que aún cae el agua, mientras que el surtidor de claro sesgo califal se asemeja a los remates o perinolas de un brasero de azófar del Museo Arqueológico de Córdoba ${ }^{11}$.

Pero no son éstos los únicos caños animalísticos califales pues, al bajar al Jardín de la Galera, advertimos otros dos semejantes en la fuente que precede al nicho del emperador Carlos $\mathrm{V}^{12}$.

Tras el Jardín de la Galera, hacia el Sur, entre el Jardín de las Damas y la Huerta de la Alcoba, se extiende en planta cuadrada el Jardín del laberinto ${ }^{13}$. Nada resta de ese lúdico vergel sino la magnífica descripción de Rodrigo Caro ${ }^{14}$ y su recuerdo en el actual Laberinto, levantado en $1910^{15}$, según las trazas del modelo en el pavimento del Cenador de la Alcoba, frente al cual se encuentra situado.

Sin embargo, nos ha quedado lo que constituía el centro de atención de aquel dédalo de murtas y arrayanes que simbolizaría el laberinto de Creta o el difícil camino de la virtud hasta la fuente de la Inmortalidad ${ }^{16}$. Trátase de una montaña artificial de cuatro huecos, imitando una gruta que se alza en medio de un estanque en el que crecen palmeras. Bajo la pétrea bóveda recubierta de mosaico que perdió su primitivo esplendor, una doble estatua femenina que oprime sus turgentes senos se refleja en el agua.

11. TORRES BALBÁS, L.: Op. cit., p. 761, fig. 616.

12. MARÍN FIDALGO, A.: Op. cit., II, p. 437.

13. Hemos seguido las denominaciones de los jardines utilizadas por Marín, A. (El Alcázar de Sevilla, passim) aprovechando la definida planta de A. Jiménez ("Dibujos de arquitectura sevillana...", p. 52) pues la atractiva planta general de cubiertas y jardines de R. Manzano (publicada in Marquesa de Casa Valdés, Jardines de España, Madrid, 1973) se presta a confusión. En realidad, desde la obra de J. Gestoso (Sevilla Monumental y Artística, I, Sevilla, 1889, pp. 388-403) se han sucedido diversas nomenclaturas que habría que precisar partiendo del plano general de Sebastián Van der Borcht publicado por R. Manzano ("Poetas y vida literaria en los Reales Alcázares de la ciudad de Sevilla" in Tres Estudios sobre Sevilla, Sevilla, 1984, p. 80) y después por A. Marín (op. cit., p. 249 , fig. 279 , vid ibidem, II, p. 435 , fig. 430 , una planta fragmentaria atribuida a Van der Borcht) y poniéndolos en relación con los nuevos documentos publicados. Por otra parte, vid también E. García Martín, "Dos planos del Alcázar de Sevilla", Boletín del Seminario de Estudios de Arte y Arqueología, Universidad de Valladolid, XLV, 1979, pp. 439-443.

14. CARO, R.: Antigüedades y Principado de la llustrísima Ciudad de Sevilla y Corografía de su convento jurídico, I, Sevilla, 1634, (ed. 1896), pp. 425-426.

15. BONET CORREA, A.: Op. cit., p. 30.

16. BONET CORREA, A.: Ibidem, siguiendo las Antigüedades... de CARO R. y LLEÓ, V.: Op. cit., p. 88 apoyándose en La Philosophia Secreta de Pérez de Moya. 
Pero no era ésta la única figura animada del conjunto pues cuatro cabezas de león y un busto barbado aparecen entre las rocas de este monte Parnaso, mandado construir por don Gaspar de Guzmán, Conde Duque de Olivares y alcaide perpetuo de los Reales Alcázares de Sevilla por orden de su señor Felipe IV. Las obras comenzaron en 1626 bajo la dirección del maestro mayor Miguel de $\mathrm{Zu}$ márraga, interviniendo también los escultores Miguel de Escurra y Martín Cárdeno ${ }^{17}$. No obstante, en 1629 , el monte fue reconstruido con los mismos materiales por decisión del siguiente maestro mayor, Diego López Bueno, quien consideraba desproporcionada la obra anterior ${ }^{18}$.

Los surtidores del estanque estaban constituidos tanto por los senos de la doncella como por las bocas de los leones, cuyas cabezas se hallan incrustadas en tres de làs esquinas del ficticio monte. Pues bien, en nuestra opinión, la cabeza de león situada en el sector sudoeste consiste en un antiguo surtidor hispanomusulmán reutilizado para el mismo fin.

Si consideramos las fuentes mencionadas más arriba cuyos caños siguen aún en uso, no parece extraño que en el estanque se aprovechara una escultura de este tipo procedente, tal vez, del propio Alcázar. La figura animal como surtidor tenía una gran tradición desde la construcción de los palacios de Madinat al-Zahra y leones en piedra sirvieron de surtidores para los estanques nazaríes como podemos contemplar aún en los jardines del Partal en la Alhambra ${ }^{19}$. Empero, los hubo también en cerámica vidriada tal el que se conserva en el Museo Arqueológico de Sevilla, hallado con motivo de unas obras realizadas en la calle Sierpes ${ }^{20}$.

La cabeza de león situada en el sector sudoeste del monte Parnaso de la fuente del Jardín del Laberinto posee el mismo concepto abstracto que apreciamos en el pequeño león surtidor de cerámica del Museo Arqueológico. El tratamiento del volumen de la cabeza en planos que le confieren un gran esquematismo, los arcos de los pliegues de los ojos, y la forma del hocico nos inducen a considerarlo una de aquellas figuras animalísticas califales, ornato de sus jardines.

Parece posible que el escultor haya tomado como modelo la antigua cabeza califal y no deja de ser probable que haya imitado sus formas en las otras tres cabezas de leones que aún contemplamos reflejándose en las aguas del estanque del Jardín del Laberinto. Comparándolas entre sí, éstas últimas son más natura-

17. MARÍN, A.: Op. cit., II, p. 459.

18. MARÍN, A.: Ibidem, II, p. 461.

19. TORRES BALBÁS, L.: Arte almohade. Arte nazarí. Arte mudéjar, "Ars Hispaniae", IV, Madrid, 1949, p. 160.

20. FERNÁNDEZ-CHICARRO, C. y FERNÁNDEZ GÓMEZ, F.: Catálogo del Museo Arqueológico de Sevilla, II. Salas de Arqueología romana y medieval, 3." ed., Madrid, 1980, p. 193. 
listas y están más animadas en su modelado que la primera en la que destaca un mayor poder de abstracción.

Ahora bien, si consideramos que, entre las obras encargadas para adorno del estanque del entonces llamado Jardín Nuevo o de la Cruz, el escultor Martín Cárdeno entregó tres cabezas de leones y después el pintor Lucas de Esquivel pintó cuatro ${ }^{21}$, no resulta difícil pensar que una de ellas existiera ya antes de que Martín Cárdeno modelara las otras tres.

No lejos de allí, otra figura de felino se mira en las aguas de la vieja alberca de la Huerta de la Alcoba, transformada en fuente del León ${ }^{22}$. No es éste otro surtidor califal aún cuando su posición en el lado menor del estanque junto con la cúpula barroca del pabellón mirador evoque reminiscencias de quioscos orientales rodeados de jardines. Y lo que sucede es que la fuerza y el prestigio del pasado islámico fue tal que la monarquía española no se sustraía a prescindir de la herencia de aquella civilización exquisita. En consecuencia, imágenes como las que hemos presentado se podían convertir y, de hecho, se convertían, finalmente, en espléndidos símbolos de poder para el común de sus súbditos.

21. MARÍN, A.: Op. cit., II, p. 459.

22. JIMÉNEZ MARTÍN, A.: "Jardines", p. 2.144, afirmando que en las obras intervino Juan Hernández (1536-1572), hijo de un morisco. No era extraño que albañiles y jardineros moriscos realizaran estas labores como se puede constatar en documentación sobre el Generalife en 1583, donde se afirma que el cuidado de los jardines "consiste en aver hombres que tengan cuenta con la cultivación y grangería de las huertas y jardines, que sean pláticas y experimentadas en ellos, y estos no los ay sino moriscos, por cuyas manos an sido siempre tratadas y gobernadas" Apud CHECA, F.: Op. cit., p. 30. Sobre el simbolismo del león en el mundo islámico vid HARTNER, W. \& ETTINGHAUSEN, R.: "The conquering Lion, the Life Cycle of a Symbol", Oriens, 17, 1964, pp. 161-171. 

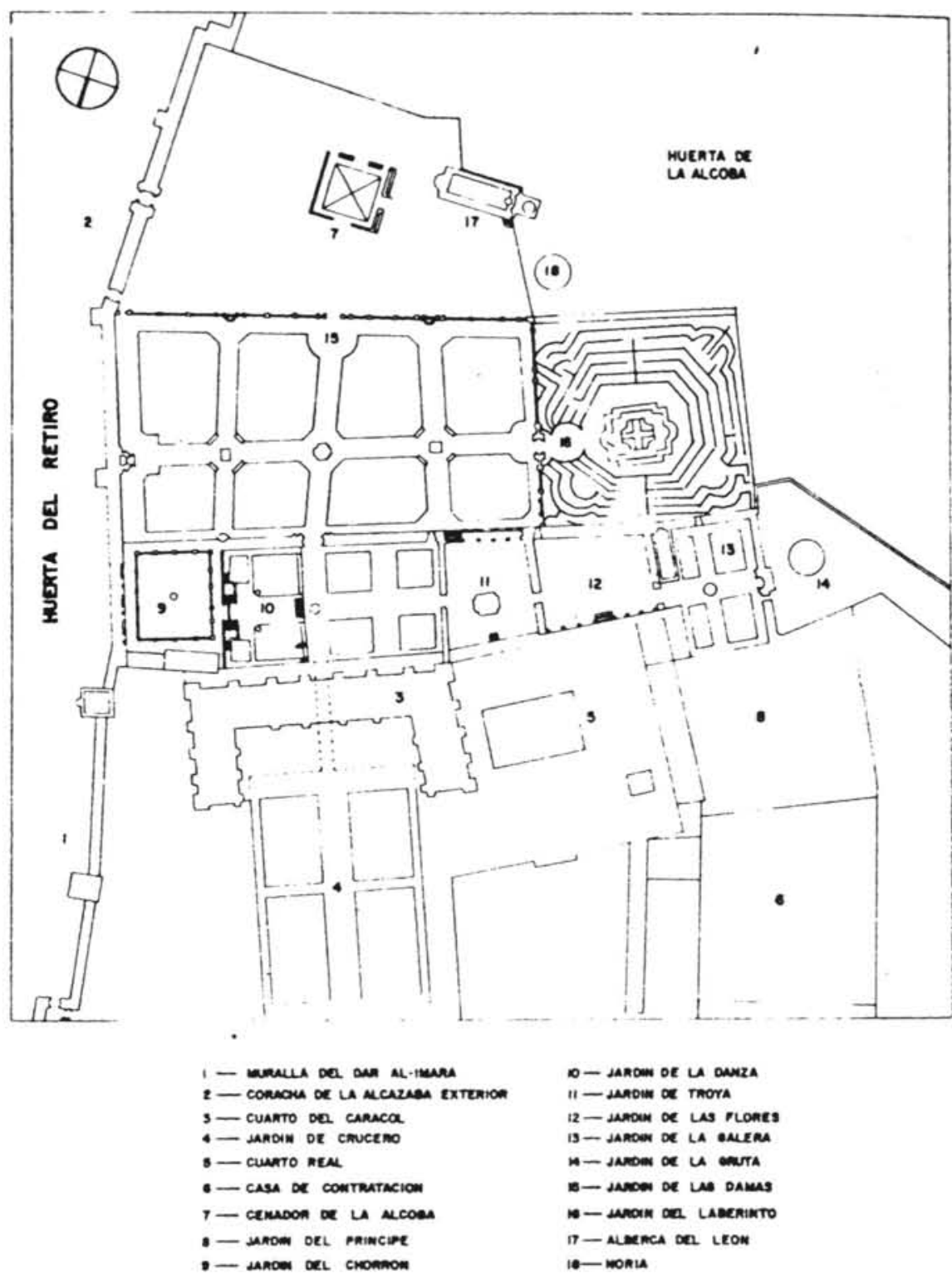

1. Planta parcial de los jardines del Alcázar de Sevilla

(A. Jiménez Martín, "Dibujos de arquitectura sevillana. El Cenador de la Alcoba", Revista de arte sevillano, n.․․ 2 , 1982, p. 52). 


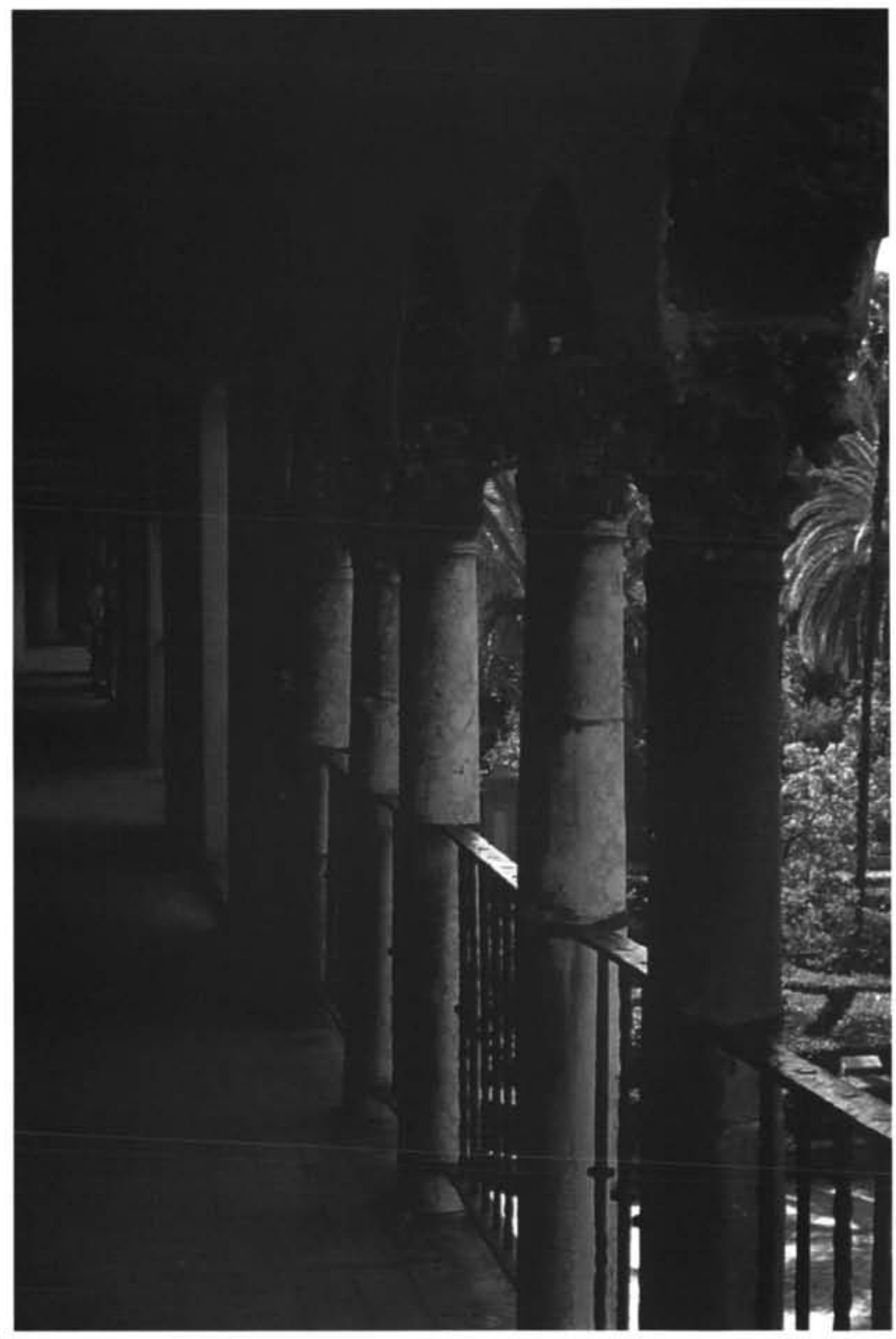

2. Galería del Grutesco. Fustes y capiteles califales (R. Cómez). 


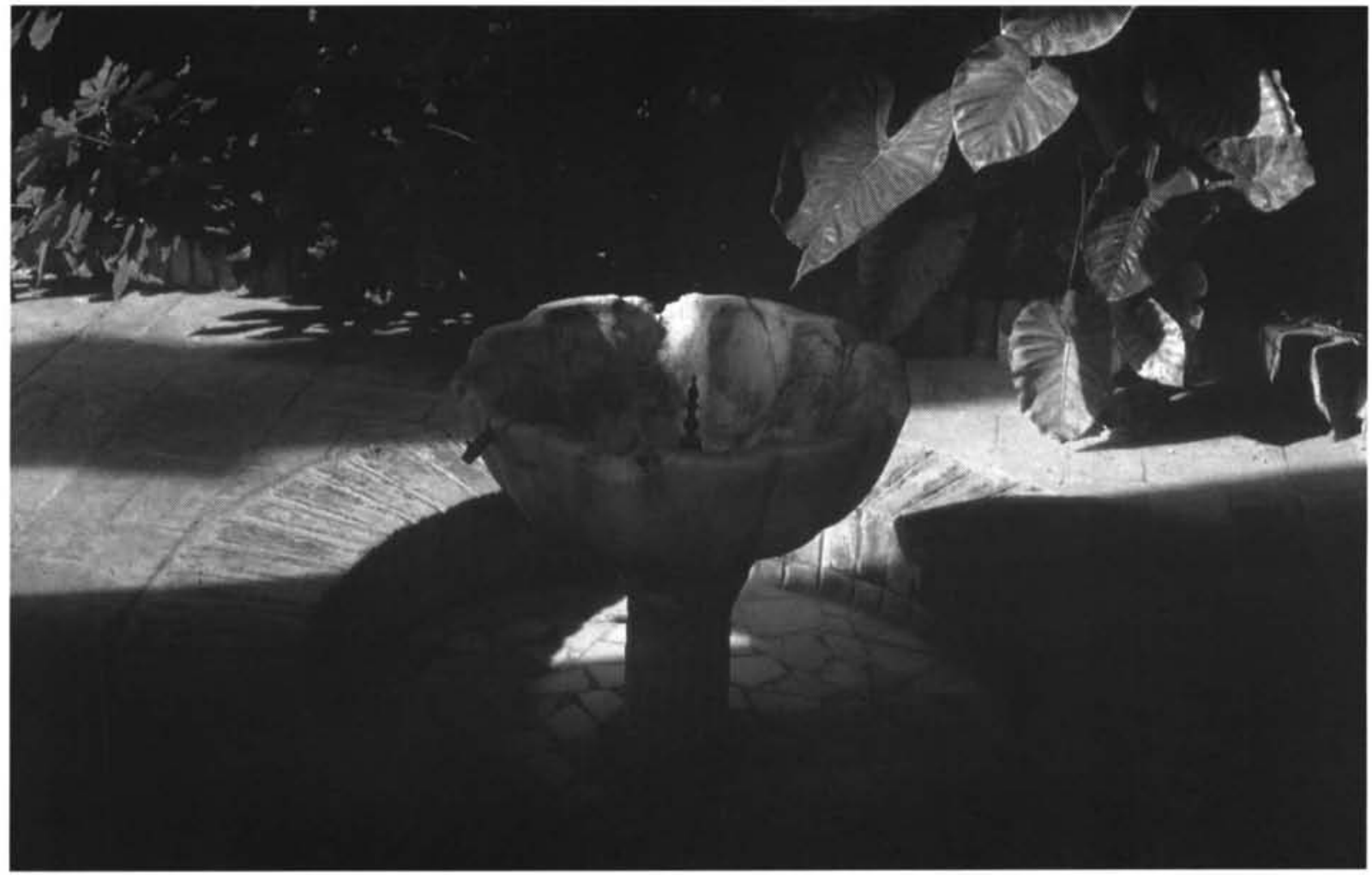

3. Patio de la Montería. Fuente en el extremo de la galería del Cuarto del Almirante. (R. Cómez). 


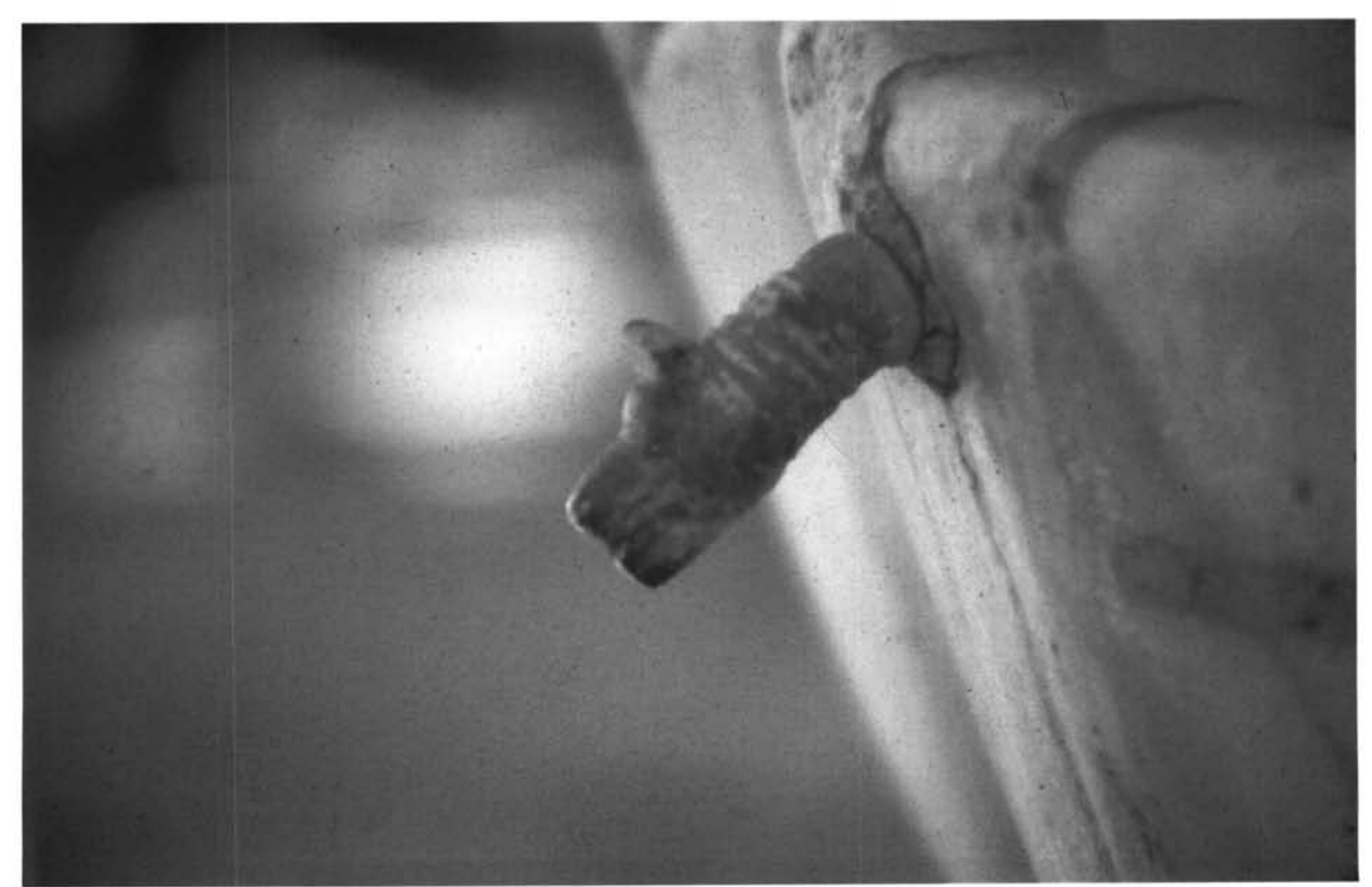




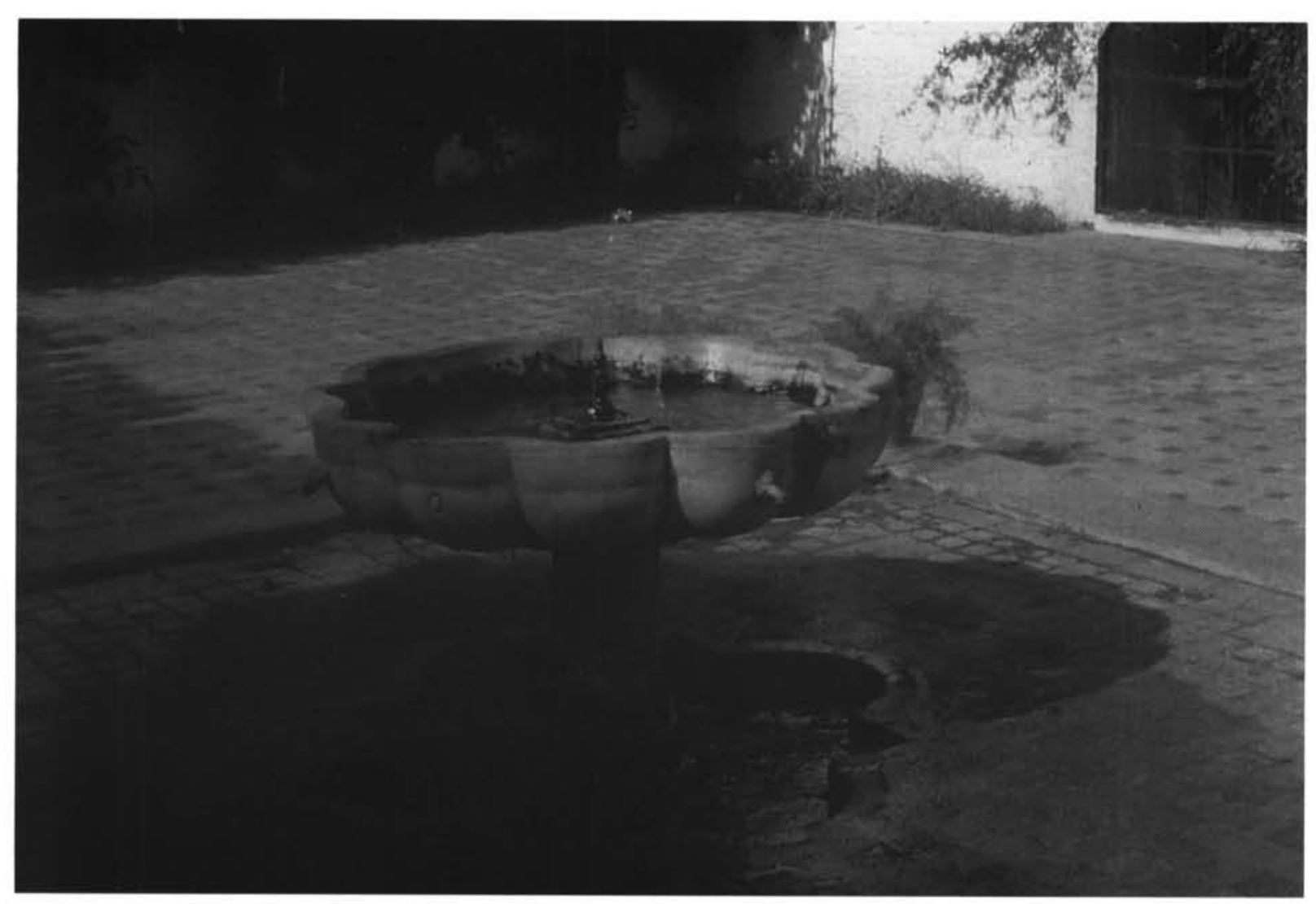




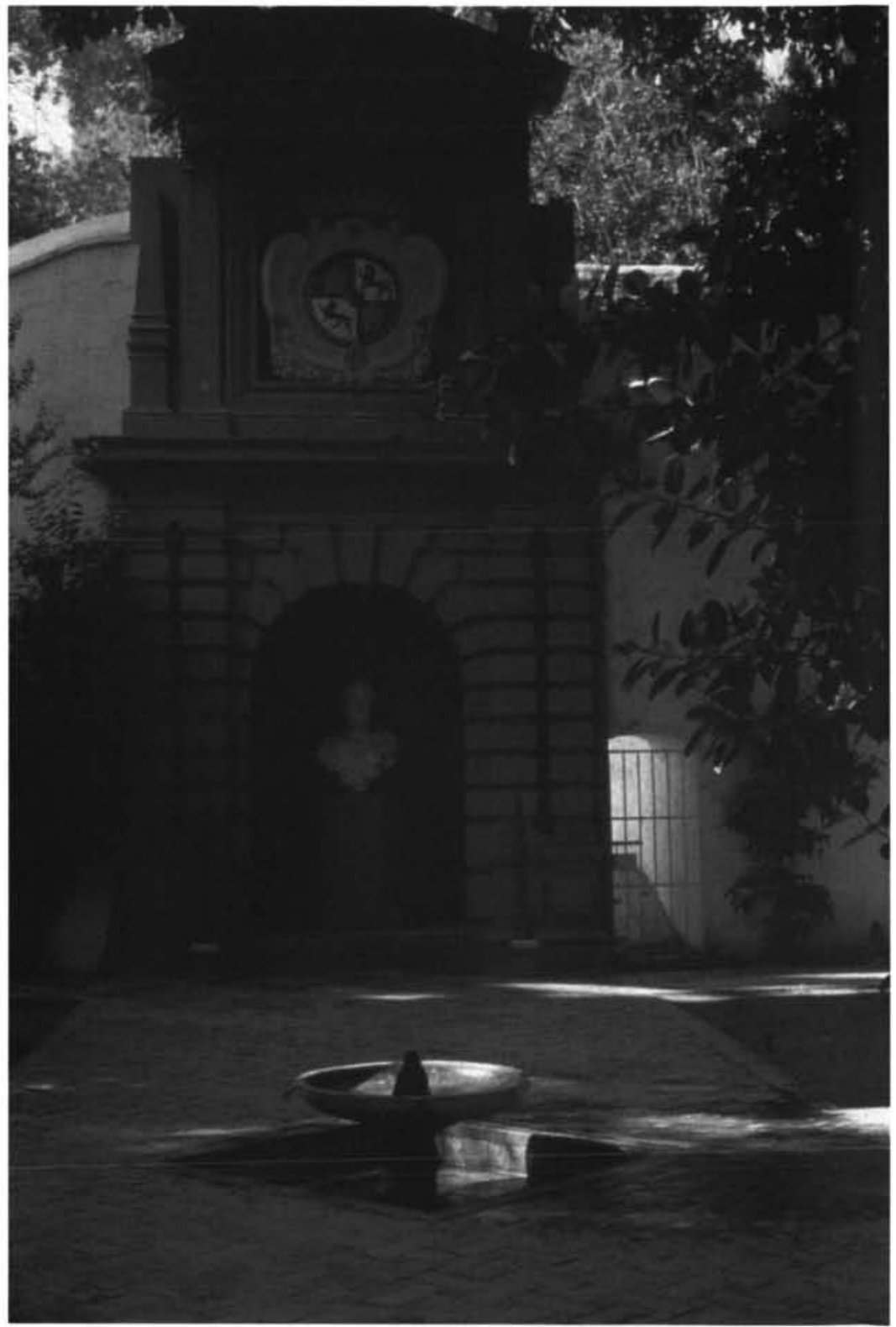

6. Jardín de la Galera. Fuente

(R. Cómez). 


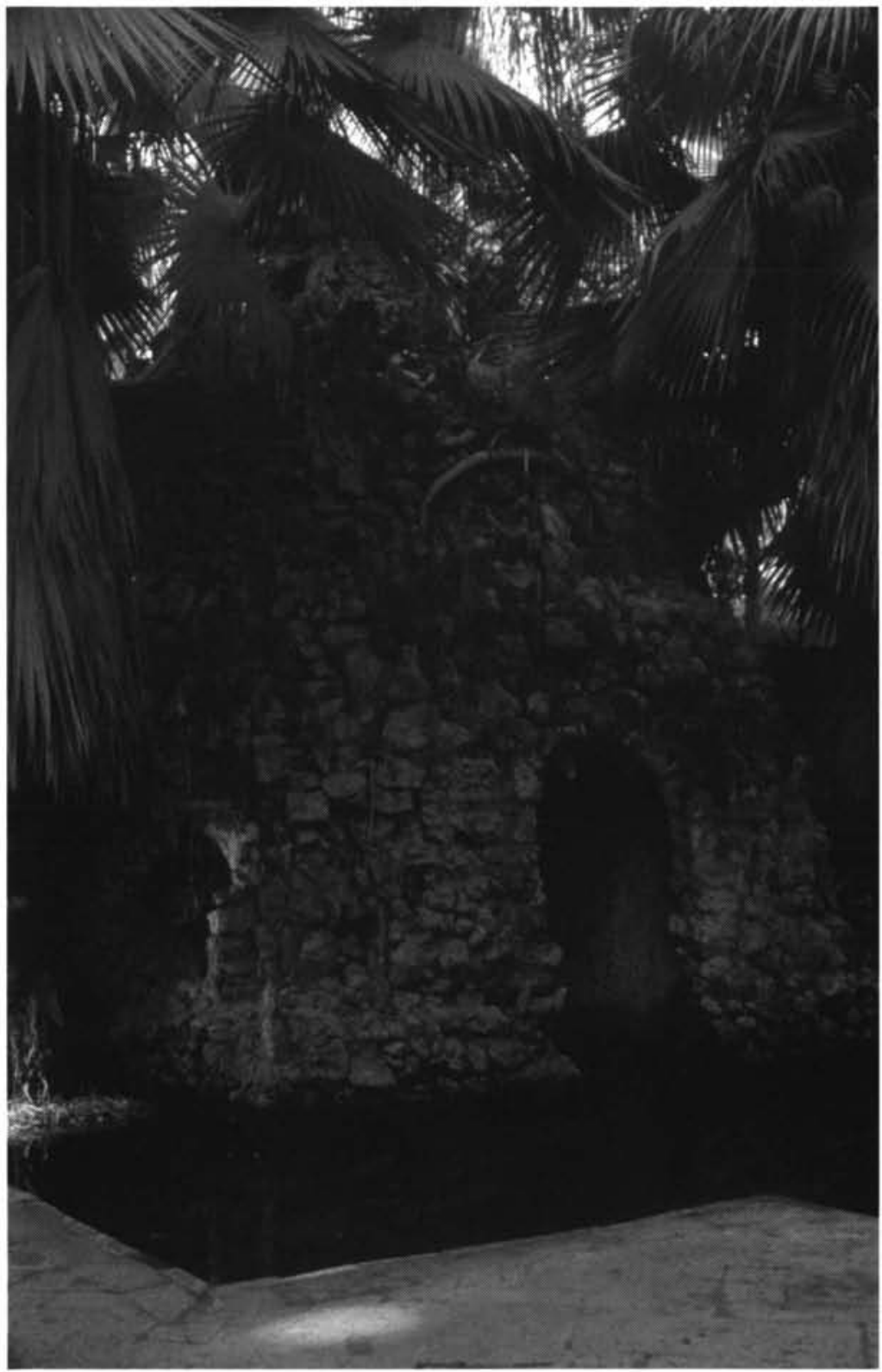

7. Jardín del Laberinto. Estanque del monte Parnaso

(R. Cómez). 


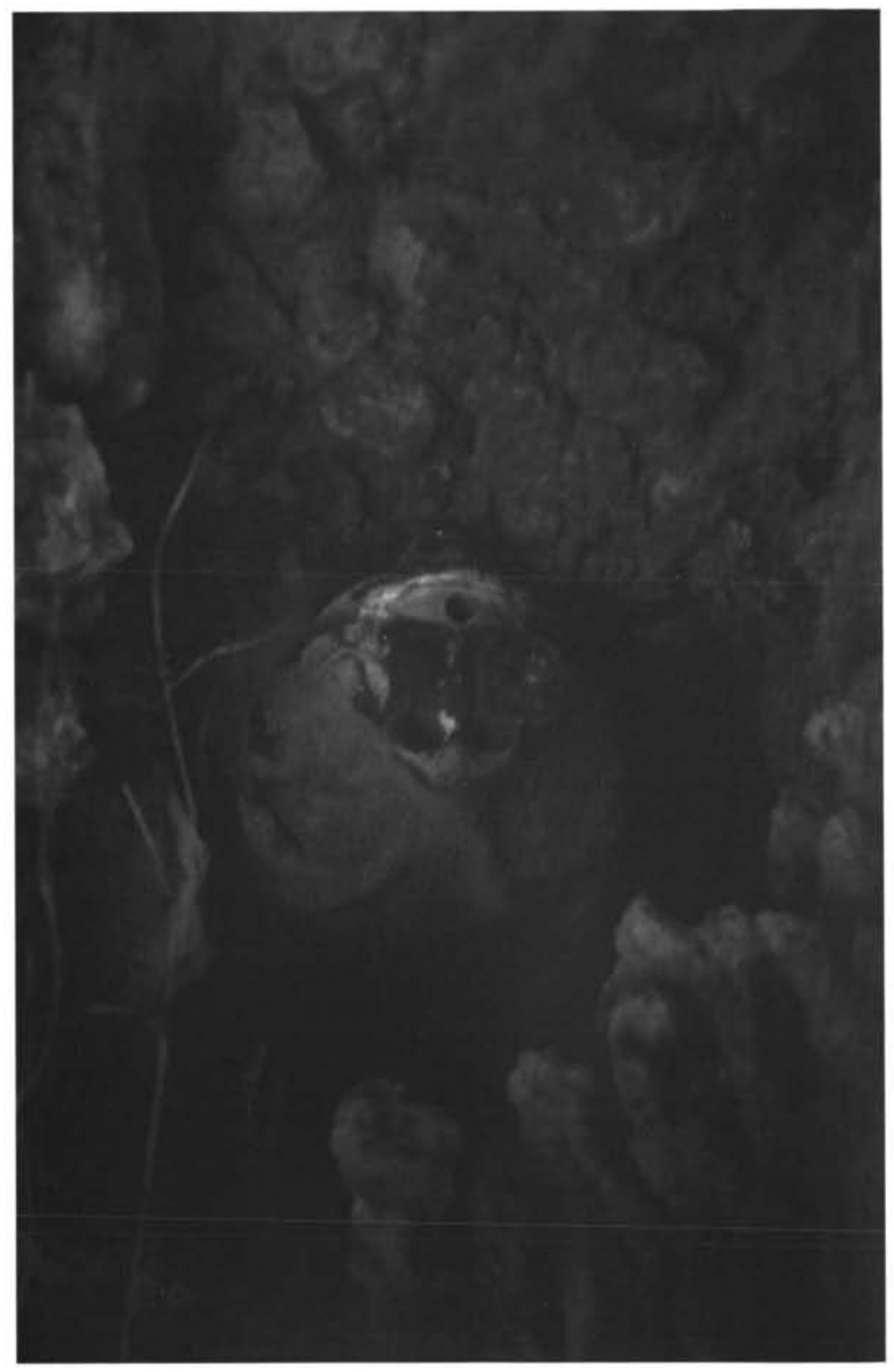

8. Jardín del Laberinto. León surtidor del estanque anterior (R. Cómez). 